\title{
MERAWAT SIKAP SOPAN SANTUN DALAM LINGKUNGAN PENDIDIKAN
}

\author{
Iwan \\ Institut Agama Islam Negeri Syekh Nurjati Cirebon \\ Email: iwan@syekhnurjati.ac.id
}

\begin{abstract}
ABSTRAK
Salah satu pendidikan karakter yang terdapat di sekolah adalah terjalinnya sikap sopan santun yang dilakukan oleh siswa kepada lingkungan sekitarnya di sekolah. Internalisasi adalah sebagai upaya atau proses memasukan pengetahuan (knowing) dan keterampilan melaksanakan (doing) itu ke dalam pribadi. Sopan santun adalah aktivitas seseorang yang dapat diamati oleh orang lain atau instrument penelitian terhadap suatu perangsang atau situasi yang dihadapi berkaitan dengan hubungan kemasyarakatan, meliputi menghormati guru/orang yang lebih tua dari kita, tolong menolong, husnudzon dan menghargai orang lain, perilaku sopan santun merupakan cerminan dari akhlak mahmudah (akhlak yang baik). Metode yang digunakan dalam penelitian ini adalah dengan menggunakan metode penelitian analisis deskriftif dengan pendekatan kualitatif. Proses merawat inilai-nilai sopan santun di lingkungan pendidikan mempunyai beberapa prosedur, mekanisme, rangkaian kegiatan, urutan pelaksanaan, desain, ruang dan waktu, yang dilakukan secara terus menerus. Untuk menciptakan situasi belajar yang akan mengembangkan pengalaman siswa, maka kegiatan pembelajaran berupa ekstrakurikuler keagamaan yang dilaksanakan terdiri dari : 1) Shalat sunat Dhuha secara berjama'ah. 2) Membaca surat Yasin. 3) Melaksanakan latihan khitobah (pidato). 4) Bimbingan Baca Tulis al-Qur'an. 5) Melaksanakan latihan Seni Hadroh. 6) Pelaksanaan Peringatan Hari Besar Islam (PHBI). 7) Pesantren Ramadhan (Sanlat).
\end{abstract}

Kata kunci: Merawat, nilai-nilai, sopan santun

\begin{abstract}
One of the character education in the school is the establishment of courtesy carried out by students to the surrounding environment at school. Internalization is an effort or process of entering knowledge (knowing) and the skills to carry out (doing) it into the person. Courtesy is a person's activity that can be observed by others or research instruments to an incentive or situation faced in relation to social relations, including respecting teachers / people who are older than us, please help, husnudzon and respect others, polite behavior is a reflection of the morals (good character). The method used in this research is to use descriptive analysis research methods with a qualitative approach. The process of caring for the values of courtesy in an educational environment has several procedures, mechanisms, a series of activities, the order of implementation, design, space and time, which are carried out continuously. To create a learning situation that will develop students' experiences, the learning activities in the form of religious extracurricular activities consist of: 1) Dhuha circumcision in congregation. 2) Read the letter Yasin. 3) Carry out khitobah exercises (speech). 4) Reading Guidance Write the Qur'an. 5) Performing Hadroh Art exercises. 6) Implementation of Commemoration of Islamic Holidays (PHBI). 7) Islamic Boarding School Ramadhan (Sanlat).
\end{abstract}


Keywords: Caring, values, manners

\section{A. Pendahuluan}

Berbicara pembentukan kepribadian tidak lepas dengan pembentukan the character of human resources. Pembentukan karakter menjadi vital dan tidak ada pilihan lagi untuk mewujudkan Indonesia baru, yaitu Indonesia yang dapat menghadapi tantangan regional dan global. Tantangan regional dan global yang dimaksud adalah bagaimana generasi muda tidak sekedar memiliki kemampuan kognitif saja, tapi aspek afektif dan moralitas juga tersentuh.Untuk itu, pendidikan karakter diperlukan untuk mencapai manusia yang memiliki integritas nilai-nilai moral sehingga anak menjadi hormat sesama, jujur dan peduli dengan lingkungan. ${ }^{1}$

Konteks globalisasi akan meniscayakan persaingan antar individu, masyarakat, bangsa dan negara yang begitu ketat, baik di tingkat lokal, regional maupun internasional. Hanya mereka yang handal, tangguh dan berkarakter yang akan mampu bersaing, dan keluar sebagai pemenang. Realitas kehidupan manusia berlaku seleksi alam, dimana manusia yang kuat, handal, memiliki daya saing dan dapat menyesuaikan diri dengan situasi yang ada akan keluar sebagai pemenang, sedangkan mereka yang lemah akan tergilas dan hanya akan menjadi penonton dalam era peradaban baru.

Tantangan globalisasi yang diikuti dengan lahirnya kerangka kompetensi abad 21, harus kita lalui dan persiapkan dengan serius, dan semua pasti sepakat bahwa kuncinya terletak pada kualitas sumberdaya manusia. Karena maju mundurnya suatu bangsa sangat tergantung pada kualitas sumber daya manusianya, walaupun Indonesia negara yang subur dan memiliki kekayaan alam yang sangat luar biasa, akan tetapi kekayaan alam saja tidaklah cukup untuk kemajuan sebuah negara, tetapi ada faktor yang tidak kalah pentingnya yaitu sumber daya manusia yang sehat, cakap, berilmu, handal, berdaya saing dan berkarakter, yang akan mampu bersaing dengan bangsa lain dalam menjawab tantangan globalisasi dengan kerangka kompetensi yang baru di abad 21. Sebagaimana ditegaskan oleh Fukuyama bahwa kekayaan alam bukanlah segalanya dalam menentukan kemajuan bangsa, tetapi kualitas

\footnotetext{
${ }^{1}$ Weinata Sairin, Pendidikan yang Mendidik, (Jakarta: Yudhistira, 2001), 211.
} 
sumber daya manusia yang sehat, cakap, berilmu dan berkarakter, itulah yang menentukan. ${ }^{2}$ Berkaitan dengan hal lain yang menentukan bahwa kualitas karakter seseorang memang sangat menentukan keberhasilan orang tersebut, begitu juga kualitas karakter suatu bangsa akan menentukan kemajuan bangsa tersebut. Searah dengan ungkapan tersebut, Goleman mengutarakan bahwa kualitas karakter adalah hal yang penting dalam menentukan keberhasilan seseorang sedangkan kualitas intelektual hanyalah menyumbang sekitar 20\% keberhasilan seseorang. ${ }^{3}$

Jika kita menengok sumberdaya manusia negeri kita saat ini, secara kolektif masih rendah dan sungguh sangat memperihatinkan, tengoklah setiap tahun jutaan sarjana negeri ini rela antri dan bahkan kolusi untuk jadi pegawai negeri daripada mengolah kekayaan alam yang dimiliki. Para pemuda kita lebih senang menjadi buruh kasar di negeri jiran daripada membuka ladang di daerah sendiri. Dan para remaja putri lebih tertarik menjadi TKW di luar negeri daripada mendampingi suami sebagai petani di bumi pertiwi. Padahal negara ini memiliki memiliki banyak potensi yang luar biasa, yang apabila diolah dan dimanfaatkan oleh tangan-tangan cerdas dan terampil para pemuda negeri, bukan mustahil akan berdampak pada kemajuan bangsa. Akan tetapi karena rendahnya sumberdaya manusia bangsa ini, semua kekayaan alam dieksploitasi besar-besaran negara lain. Sehingga walaupun dari sumber kekayaan alam kita kaya peringkat Indeks Pembangunan Manusia (Human Development Index atau HDI) selalu rendah, seperti contoh peringkat HDI Indonesia pada tahun 2011, yang dirilis Koran Tempo pada tanggal 2 November, negara ini berada pada peringkat 124 dari 187 negara. Hal ini menunjukan indikator buruknya kondisi sosial ekonomi, tingkat pendidikan, kesehatan dan gizi serta pelayanan sosial bangsa Indonesia. Sungguh sangat ironis, padahal negara ini memiliki modal fisik yang luar biasa yaitu sumberdaya alam yang sangat kaya dan melimpah ruah sebagai modal untuk pembangunan di segala bidang, sebagaimana disampaikan Hertzmark dalam sebagai berikut:

"Indonesia merupakan negara yang memiliki modal fisik (physical capital) awal yang kaya. Dengan luas laut terluas (5,8 juta $\mathrm{km} 2)$ dan jumlah pulau terbanyak (17.508), Indonesia memiliki potensi sumber daya alam luar biasa. Bayangkan, Indonesia adalah tempat hidup bagi $37 \%$ spesies dunia, $30 \%$ hutan bakau dunia, dan 18\% terumbu karang dunia. Hutan tropis Indonesia merupakan hutan terbesar ketiga setelah Brazil dan Republik Demokrasi Congo. Belum lagi hasil tambang, baik berupa minyak

\footnotetext{
${ }^{2}$ F. Fukuyama, Trust; Kebajikan Soail dan Penciptaan Kemakmuran, (Penerbit: Qalam, Yogyakarta, 1995), terj. Ruslani , 355.

${ }^{3}$ Daniel Goleman, Emotional Intelegence; Kecerdasan Emosional, (Jakarta : Gramedia, 1990), 44.
} 
dan gas bumi maupun sumber-sumber mineral lainnya Produksi minyak Indonesia pernah mencapai rata-rata 1685 ribu barrel/hari pada 1977". 4

Akan tetapi semua modal fisik yang berupa kekayaan alam belum mampu meningkatkan peringkat Indeks Pembangunan Manusia (Human Development Index atau $H D I)$ bangsa ini secara signifikan baik di tingkat regional maupun internasional. Dan yang terjadi saat ini adalah rusaknya lingkungan alam sebagai dampak eksploitasi yang hanya mengejar keuntungan jangka pendek, dan tak perduli pada dampak lingkungan jangka panjang. Kemudian permasalahan di atas diperparah lagi dengan permasalahan moral dan karakter bangsa yang ditandai dengan maraknya korupsi, kolusi dan nepotisme, suburnya perilaku merusak diri, perilaku kekerasan, dan tawuran yang hampir setiap saat menghiasi media cetak dan elektronik di negara ini.Thomas Lickona mengungkapkan ada sepuluh tandatanda zaman yang harus diwaspadai, karena bila tanda-tanda tersebut sudah ada, maka sebuah bangsa tengah menuju kehancuran. Tanda-tanda zaman itu meliputi (1) meningkatnya kekerasan di kalangan remaja, (2) penggunaan kata-kata dan bahasa yang buruk, (3) pengaruh peer group yang kuat dalam tindak kekerasan, (4) meningkatnya perilaku merusak diri, seperti penggunaan alkohol, narkoba dan seks bebas, (5) semakin kaburnya pedoman moral baik dan buruk, (6) menurunnya etos kerja, (7) semakin rendahnya rasa hormat kepada orang tua dan guru, (8) rendahnya rasa tanggung jawab individu dan warga negara, (9) membudayanya ketidakjujuran, dan (10) adanya saling curiga dan kebencian diantara sesama. $^{5}$

Bila dicermati dengan seksama, hampir semua tanda-tanda zaman yang disampaikan Thomas Lickona tengah melanda bangsa kita, mulai dari kekerasan, penggunaan kata-kata yang kasar, perilaku merusak diri, menurunnya etos kerja, rendahnya rasa hormat, tanggung jawab serta maraknya ketidakjujuran. Melihat fenomena tersebut adalah fardu ain bagi semua elemen bangsa, dan pemerintah untuk melakukan berbagai upaya yang serius, kongkrit, tepat, dan terpadu agar bangsa dan negeri tercinta ini dapat diselamatkan dari kehancuran. Karena semua fenomena di atas mulai dari rendahnya sumberdaya manusia, buruknya Indeks Pembangunan Manusia (Human Development Index) bangsa ini, massifnya korupsi, suburnya perilaku merusak diri, kekerasan dan tawuran serta tanda-tanda zaman yang disampaikan

\footnotetext{
${ }^{4}$ Tim BSNP, Paradigma Pendidikan Nasional Abad XXI, (Jakarta: Buletin BSNP, 2012), 3.

${ }^{5}$ Thomas Lickona, Educating for Character, Mendidik untuk Membentuk Karakter; Bagaimana Sekolah Dapat Mengajarkan Rasa Hormat dan Tanggung Jawab, terj. Juma Wadu Wamaungu Editor; Uyu Wahyudin dan Suryani, ( Jakarta: Bumi Aksara, 2012), 12.
} 
Lickona, menunjukan ketidakberhasilan pendidikan dalam menanamkan nilai-nilai luhur dan sikap terpuji di setiap jenjang pendidikan. Fenomena tersebut secara tidak langsung mengungkapkan belum sepenuhnya terpenuhi apa yang diungkapkan dalam paradigma pendidikan nasional:

"pendidikan nasional yang berfungsi mengembangkan kemampuan dan membentuk watak serta peradaban bangsa yang bermartabat dalam rangka mencerdaskan kehidupan bangsa". 6

Permasalahan karakter bangsa dan rendahnya sumber daya manusia di negara ini, menunjukkan bahwa pendidikan belum mampu membangun sumberdaya manusia yang berkualitas dan berkarakter. Praktik pendidikan yang terjadi di sekolah-sekolah saat ini berupa latihan sekolastik, yang mengasah kemampuan kognitif yang sangat sederhana di tingkat paling rendah. Dengan demikian, harus ada upaya yang serius untuk mengatasi rendahnya kualitas sumberdaya manusia, dan permasalahan karakter bangsa yang sekaligus untuk menyongsong tantangan globalisasi abad 21, dengan melakukan pembenahan dalam praktik pendidikan nasional kita. Kita harus berani memperbaiki praktik pendidikan bangsa ini, sehingga mampu mewujudkan tujuan pendidikan nasional, mampu memberikan solusi atas rendahnya kualitas sumberdaya manusia, mampu mengatasi permasalahan moral dan karakter yang tengah melanda bangsa, dan mampu mengantisipasi perkembangan masa depan dan tantangan globalisasi abad 21. Dalam konteks globalisasi, pendidikanharusnya mampu mempertahankan budaya dan jati diri bangsa di tengah-tengah gencarnya gempuran beragam budaya dan peradaban bangsa lain. Sebagai sebuah negara yang kaya akan suku, dan budaya yang beraneka ragam harus mampu menjadi bangsa yang mandiri dalam arti sanggup memenuhi berbagai kebutuhan masyarakat sesuai dengan harapan, cita-cita, dan impiannya, sebagaimana diamanatkan para pendiri dan pejuang negera ini dalam pembukaan UUD 1945, yaitu mencerdaskan kehidupan bangsa, yang dilanjutkan secara lebih spesifik melalui tujuan pendidikan yang tercantum dalam Undang-Undang Sistem Pendidikan Nasional, No 20 Tahun 2003.

Tujuan pendidikan nasional yang tercantum dalam Undang-Undang Sistem Pendidikan Nasional, No. 20 Tahun 2003 Pasal 3, sebagai landasan operasional dalam pendidikan nasional, sebenarnya sudah cukup ideal, dalam mencerminkan keinginan dan harapan bangsa ini untuk mewujudkan kualitas sumber daya manusia yang yang beriman dan bertakwa kepada Tuhan Yang Maha Esa, berakhlak mulia, sehat, berilmu, cakap, kreatif, mandiri,

${ }^{6}$ Departemen Pendidikan Nasiona, Undang-undang RI No.20 tahun 2003 Tentang Sistem Pendidikan Nasional, (Jakarta : Depdiknas, 2003), 13. 
demokratis bertanggung jawab, yang akan mampu bersaing dengan bangsa lain dalam menjawab tantangan globalisasi

Pertanyaan mendasar, mengapa tujuan pendidikan di atas belum tercapai, padahal segala daya upaya telah kita lakukan, trilyunan dana setiap tahun telah dihabiskan pada bidang ini?. Sebagai jawabannya mari kita analisis dari hal yang paling mendasar, mulai dari subjek pendidikan. Manusia atau individu adalah subjek dalam proses pendidikan yang lebih spesifik dalam hal ini adalah para peserta didik. Logikanya ketika menetapkan sebuah tujuan dalam pendidikan, maka terlebih dahulu harus memahami secara utuh mengenai sasarannya, lebih jelasnya ketika menentukan tujuan pendidikan yang sasaranya adalah peserta didik, maka segenap elemen dasar, dan dimensi manusia sebagai individu harus dipahami secara utuh dan menyeluruh (holistik). Mencermati Tujuan pendidikan yang tercantum dalam Undang-Undang Sistem Pendidikan Nasional, No. 20 Tahun 2003 Pasal 3, secara eksplisit telah menggambarkan manusia Indonesia yang seutuhnya, yaitu manusia yang berkembang secara utuh dan seimbang semua dimensi kemanusiannya (manusia holistik). Tetapi dalam penjabaran tujuan pendidikan nasional belum menunjukan adanya pengklasifikasian potensipotensi manusia yang perlu dikembangkan dalam proses pembelajaran di kelas dan sekolah. ${ }^{7}$ Potensi-potensi tersebut meliputi aspek fisik, emosional, sosial, kreatifitas, intelektual dan spiritual. Sehingga dalam praktiknya belum menggambarkan adanya upaya membangun manusia Indonesia secara utuh dan menyeluruh (holistik).

Dalam praktiknya pendidikan harus memperhatikan enam potensi atau aspek yang merupakan elemen penting yang harus dikembangkan dari peserta didik, karena keenam elemen ini memiliki peran mendasar dalam proses pembelajaran. Jadi pada hakekatnya tujuan pendidikan nasional kita sebetulnya sudah mencerminkan tujuan membangun peserta didik secara holistik, akan tetapi dalam prosesnya belum memperhatikan dan mengembangkan elemen-elemen dasar potensi yang dimiliki manusia secara utuh dan menyeluruh (holistik). Praktek pendidikan kita belum mampu mengembangkan keenam aspek penting peserta didik secara optimal. Pendidikan kita cenderung berorientasi pada kecerdasan akadamik dan kurang memperhatikan aspek lain seperti kecerdasan emosional, spiritual, kreativitas dan estetika. Sehingga sebagian generasi kita saat ini banyak yang lemah dalam pengendalian emosi, gersang dalam kehidupan spiritual dan miskin kreativitas, kurang peduli lingkungan , rendah

\footnotetext{
${ }^{7}$ Ratna Megawangi, PendidikanKarakter, Solusi yang Tepat untuk Membangun Bangsa, (Cimanggis: Indonesia Heritage Foundation, 2004), 27.
} 
dalam sikap moralnya, dan kurang memiliki daya saing. Fenomena ini berdampak pada lemahnya sumberdaya manusia Indonesia, dan munculnya berbagai pristiwa yang diakibatkan dari rendahnya moral dan karakter bangsa.

Praktik pendidikan kita saat ini, masih memperaktekan pola pendidikan abad 19, yang reduksionis, linier dan dipengaruhi positivisme yang begitu kental. Reduksionisme dalam pendidikan saat ini telah merusak makna pendidikan yang dibatasi dengan pesekolahan, proses belajar mengajar, kelas, buku teks, dan terakhir penilaian selalu diukur dengan angka dan berakhir dengan ujian nasional. ${ }^{8}$ Orientasi sistem pendidikan kita cenderung menyiapkan anak untuk pintar secara akademik yang yang identik dengan kemampuan otak kiri. Diperparah lagi dengan proses pembelajaran yang berpusat pada guru dan sistem penilaian yang cenderung kuantitatif untuk semua materi pelajaran. Kekeliruan ini makin sempurna dengan adanya upaya pengkerdilan makna pendidikan lewat kebijakan ujian nasional dalam aspek kognitif yang menentukan kelulusan anak dengan mengabaikan aspek dan potensi lain yang dimiliki anak. Padahal anak adalah manusia diciptakan Allah dengan berbagai potensi dan dibekali dengan berbagai kecerdasan, yang memerlukan upaya maksimal dalam membantu mereka dalam mengembangkan seluruh potensi yang dimilikinya. Maka mulai dari perencanaan, pelaksanaan, dan penilaianya harus dilakukan secara utuh dan mencakup segenap aspek yang ada pada diri anak.

Inilah salah satu penyebab kegagalan sistem pendidikan kita dalam mewujudkan manusia yang berkembang secara holistik, sesuai tujuan pendidikan nasional. Sehingga praktik-praktik membuat berdampak pada sulitnya peserta didik untukmenemukan relevansi makna dan nilai yang didapat di sekolah dan dalam kehidupan nyata padahal pendidikan harus bermakna bagi semua peserta didik, sehingga apa yang mereka dapat, bermanfaat dalam kehidupan mereka. Dengan melihat berbagai permasalahan yang ada, saat ini kita membutuhkan model pendidikan yang berpusat pada siswa dan dibangun di atas asumsi yang eksplisit mengenai adanya keterkaitan, keseluruhan dan menjadikan manusia yang seutuhnya. Bangsa ini membutuhkan model pendidikan yang dalam praktiknya mampu mengembangkan seluruh aspek manusia secara keseluruhan, pendidikan yang mampu menghantarkan seseorang untuk menemukan identitas, makna dan tujuan hidupnya, melalui interaksi antara guru, orang tua, teman sebaya dan hubungannya dengan masyarakat, lingkungan tempat

${ }^{8}$ Dasim Budimansyah, Penguatan Pendidikan Kewarganegaraan Untuk Membangun Karakter Bangsa, ( Bandung: Widya Aksara Press, 2010), Iii-iv. 
mereka tinggal, alam sekitar dan hubungan mereka dengan nilai-nilai spiritual. Model ini adalah model pendidikan holistik, yang berupaya untuk mengarahkan seorang individu dapat menemukan identitas, makna dan tujuan hidup melalui hubungannya dengan masyarakat, lingkungan alam, dan nilai-nilai spiritual. ${ }^{9}$

Secara historis pendidikan holistik merupakan suatu respon atas krisis lingkungan, krisis budaya, dan krisis moral pada abad ini yang bertujuan untuk mendorong para para pelajar, mahasiswa dan kaum muda sebagai generasi penerus bangsa untuk dapat hidup arif, bijaksana dan bertanggung jawab dalam suatu masyarakat yang saling pengertian, saling menghormati serta ikut berperan dalam pembangunan masyarakat, bangsa dan negara bahkan dunia dan alam semesta. Pakar pendidikan holistik menyatakan bahwa pendidikan holistik adalah:

"suatu upaya membangun secara utuh dan seimbang pada setiap murid dalam seluruh aspek pembelajaran, yang mencakup spiritual, moral, imajinatif, intelektual, budaya, estetika, emosi dan fisik yang mengarahkan seluruh aspek-aspek tersebut ke arah pencapaian sebuah kesadaran tentang hubungannya dengan Tuhan yang merupakan tujuan akhir dari semua kehidupan didunia”. ${ }^{10}$

Jadi pendekatan pendidikan yang tepat utuk mencapai tujuan pendidikan nasional kita adalah pendidikan holistik, karena model pendekatan ini membantu mengembangkan potensi peserta didik secara optimal untuk menjadi manusia yang utuh (holistik) dalam suasana pembelajaran yang menyenangkan, demoktaris dan humanis melalui pengalaman dalam interaksi dalam lingkungan keluarga, sekolah dan masyarakat. Melalui pendidikan holistik, peserta didik diharapkan dapat menjadi dirinya sendiri, memahami tujuan hidup, serta mengerti bagaimana dia harus hidup dalam kapasitasnya sebagai makhluk individu dan makhluk sosial. Maka dari itu untuk mempersiapkan sumber daya manusai yang berkualitas dalm menghadapi tantangan abad 21 dan mengatasi permasalahan karakter termasuk krisis ekologi dan krisis moral sudah saatnya kita mempraktekan pendidikan holistik, pendidikan yang memadukan aspek intelektual, emosional dan religius dengan mengintegrasikan pendidikan karakter sebagai core utama dalam prosesnya. Apabila hal ini dikembangkan dengan benar, maka akan terbentuk manusia yang berjiwa seutuhnya (holistik), yang

\footnotetext{
${ }^{9}$ C. Lennox, Do Companies Successfully Engage in Opinion shopping?: Evidence from The UK. (Journal of Accounting and Economics, 29, 2000), 17.

${ }^{10}$ Thomas Lickona, Educating for Character............, 12. 
mencerminkan karakter yang unggul, karena secara umum pendekatan ini menekankan pada tujuan membentuk karakter anak yang selaras dengan nilai moral dan etika yang berlaku. ${ }^{11}$

Beberapa tahun terakhir budaya keramahan dan sopan santun di Indonesia mengalami penurunan. Hal ini dapat dilihat dari generasi muda atau remaja yang cenderung kehilangan etika dan sopan santun terhadap teman sebaya, orang yang lebih tua, guru bahkan terhadap orang tua.Siswa tidak lagi menganggap guru sebagai panutan, seorang yang memberikan ilmu dan pengetahuan yang patut di hormati dan disegani.

Merosotnya budaya sopan santun siswa dipengaruhi banyak faktor, baik faktor tersebut dari siswa, dari guru yang merupakan faktor internal ada juga faktor dari eksternal.Perkembangan Teknologi Informasi dan Komunikasi atau yang lebih akrab kita sebut TIK atau ICT, terkadang menjadi kambing hitam dalam masalah ini. Tetapi bukan hanya TIK atau ICT yang menjadi faktor eksternal, pengaruh moderenisasi kultur, pergaulan bebas dan penyalahgunaan obat-obat terlarang juga mengambil peranan dalam proses hilangnya sopan santun siswa terhadap guru.

Adapun faktor-faktor eksternal yang mempengaruhinya yaitu :

1. Pengaruh perkembangan TIK, kebebasan mengakses informasi yang didukung oleh akses dari internet yang mudah melalui laptop, tab, malahan dari handphone / smartphone sehingga mempengaruhi pikiran siswa.

2. Moderenisasi kultur, kemudahan akses internet membuat siswa bisa melihat budaya dari negara lain. Yang secara tidak langsung mereka mengaplikasikan dikehidupan sehari-hari tanpa adanya filterisasi terhadap budaya yang diambil.

3. Pergaulan bebas, merupakan efek dari moderenisasi kultur yang tidak sesuai dengan adat istiadat Indonesia. Hal ini akan menimbulkan sifat meniru budaya barat yang cendrung bebas tanpa ada ikatan adat istiadat yang telah lama berlaku dalam kehidupan masyarakat Indonesia.

4. Penyalahgunaan obat-obat terlarang, sifat labil dalam diri siswa akan membuat siswa mencari-cari jati dirinya. Bila mana hal ini tidak tersalur secara positif, siswa akan terjerumus dalam kenikmatan semu obat-obat terlarang yang akan berpengaruh pada tingkah laku siswa tersebut.

\footnotetext{
${ }^{11}$ Thomas Lickona, Educating for Character ............, 17.
} 
5. Kurangnya pembiasaan sopan santun di rumah. Sebagian besar waktu anak dihabiskan di rumah atau dilingkungan keluarga sehingga sikap orang tua yang tidak mencerminkan norma-norma kesopanan akan mudah ditiru anak.

\section{B. Pembahasan}

1. Pengertian dan Peranan Nilai Dalam Dunia Pendidikan

Menurut E. Sumantri bahwa nilai merupakan hal yang terkandung dalam hati nurani manusia yang lebih memberi dasar dan prinsif akhlak yang merupakan standar dari keindahan dan efisiensi atau keutuhan kata hati (potensi). ${ }^{12}$ Berdasarkan uraian tersebut, bahwa nilai berada pada lubuk hati yang paling dalam pada diri manusia, sehingga adakalanya manusia berani mengorbankan dirinya daripada mengorbankan nilai keyakinannya. Mengandung arti bahwa keyakinan nilai dalam diri manusia adalah segala-galanya, sudah bersatu dalam diri dan kehidupannya.

Tamsikudin ${ }^{13}$ menyetujui pemikiran Kupperman yang mengatakan bahwa nilai adalah patokan normatif yang mempengaruhi manusia dalam menentukan pilihan diantara cara-cara tindakan alternatif. ${ }^{14}$ Definisi ini memiliki tekanan utama pada norma sebagai faktor eksternal yang mempengaruhi perilaku manusia. Definisi ini lebih mencerminkan pandangan sosiolog, seperti sosiolog pada umumnya. Kupperman memandang norma sebagai salah satu bagian terpenting dari kehidupan sosial, sebab dengan penegakan norma seseorang justru dapat merasa tenang dan terbebas dari segala tuduhan masyarakat yang akan merugikan dirinya. Oleh sebab itu, salah satu bagian terpenting dalam proses pertimbangan nilai (value judgement) adalah pelibatan nilai-nilai normatif yang berlaku dimasyarakat.

Pengertian lain dikemukakan Rokeach menurutnya nilai merupakan keyakinan abadi (an enduring belief) yang menjadi rujukan bagi cara bertingkah laku atau tujuan akhir eksistensi (mode of conduct or end state of exsistence) yang merupakan preferensi tentang konsepsi yang lebih baik (conception of the preferable) atau konsepsi tentang segala sesuatu yang secara personal dan sosial dipandang lebih baik (thats is personally or socially preferable). Lebih jauh dikatakannya bahwa nilai itu merupakan sesuatu yang memiliki harga,

\footnotetext{
${ }^{12}$ E. Sumantri, Buku Materi Pembinaan Gnerasi Muda, (Jakarta: Universitas Terbuka, 1993), 3.

${ }_{13}$ Tamsikudin, Pengembangan Model Pembinaan Akhlak Dalam Pembentukan Pribadi Sehat Di Lembaga Pemulihan Sosial (Studi Kasus di Balai Pemulihan Sosial Wanita Tuna Susila Cirebon), (Bandung: UPI Bandung, Disertasi, 2012), 9.

${ }^{14}$ Joel. J. Kupperman, Character, (New York: Oxford University Press, 1991), 50.
} 
-makanya itu dikatakan bernilai- adil, baik, benar, dan indah, serta menjadi pedoman atau pegangan dalam bertindak. ${ }^{15}$ Senada dengan itu Djahiri memberikan ruang lingkup yang sederhana mengenai nilai, menurut beliau nilai dapat dikatakan dengan "sesuatu yang berharga, baik menurut standar logika (benar-salah), estetika (bagus-buruk), etika (adil, layaktidak layak), agama (dosa, dan haram-halal), dan hukum (sah-absah) serta menjadi acuan dan atau sistem keyakinan diri maupun kehidupannya". ${ }^{16}$

Sementara Allport dalam Sauri mendefinisikan nilai sebagai sebuah keyakinan yang membuat seseorang bertindak atas dasar pilihannya. ${ }^{17}$ Sementara Kupperman menafsirkan nilai sebagai patokan normatif yang mempengaruhi manusia dalam menentukan pilihannya diantara cara-cara tindakan alternatif, sementara Kluckhon masih dalam Sauri mendefinisikan nilai sebagai konsepsi (tersirat atau tersurat, yang sifatnya membedakan individu atau ciri-ciri kelompok) dari apa yang di inginkan, yang mempengaruhi pilihan terhadap cara, tujuan antara dan tujuan akhir tindakan. ${ }^{18}$ Menurutnya definisi tersebut memiliki banyak implikasi terhadap pemaknaan nilai-nilai budaya dan sesuatu dipandang bernilai apabila dipersepsi sebagai sesuatu yang diinginkan.

Lain halnya dengan Kees Bertens yang mengemukakan bahwa nilai sekurangkurangnya memiliki tiga ciri sebagai berikut: (1) nilai berkaitan dengan subyek. Kalau tidak ada subyek yang menilai, maka tidak ada nilai juga. Entah manusia hadir atau tidak, gunung tetap meletus. Tapi untuk dapat dinilai sebagai "indah" atau "merugikan", letusan gunung itu memerlukan kehadiran subyek yang menilai. (2) nilai tampil dalam suatu konteks praktis, dimana subyek ingin membuat sesuatu. Dalam pendekatan yang semata-mata teoretis, tidak akan ada nilai. (Hanya menjadi pertanyaan apakah suatu pendekatan yang secara murni teoretis bisa diwujudkan). (3) menyangkut sifat-sifat yang "ditambah" oleh subyek pada sifatsifat yang dimiliki oleh obyek. Nilai tidak dimiliki oleh obyek pada dirinya. ${ }^{19}$

Menurut Hakam nilai adalah gagasan seseorang atau kelompok tentang sesuatu yang dipandang baik, benar, indah, bijaksana sehingga gagasan itu berharga dan berkualitas untuk

\footnotetext{
${ }^{15}$ M. Rokeach, The Nature of Human Value, (New York: The Free Press, 1973), 5-10.

16 A. K. Djahiri, PendidikanNilai Moral; Hand Out Perkuliahan S-2 Program Studi Pendidikan Umum. (Bandung: PPS UPI, 2002), 23.

${ }^{17}$ Sofyan Sauri, Konsep Pendidikan Umum, (Bandung: UPI Bandung, 2015), h. 75.

${ }^{18}$ Sofyan Sauri, Konsep Pendidikan............., 90.

${ }^{19}$ Kees Bertens, Sejarah Filsafat Yunani, (Jakarta : Rajawali, 2001), 141.
} 
dijadikan pegangan atau pedoman dalam bersikap dan bertindak. ${ }^{20}$ Lebih jauh dikatakan bahwa meskipun manusia memiliki potensi untuk bernilai, namun gagasan manusia tentang nilai tidak dibawanya sejak lahir, nilai bagi seseorang tumbuh dan berkembang sesuai dengan kesadarannya, dengan sesuatu yang disetujuinya sebagai sesuatu yang baik, yang benar, yang indah, yang berkualitas dan berharga. Oleh karena itu, kesadaran terhadap nilai harus dicari setiap manusia, manusia memiliki kewajiban untuk menemukan nilai agar dirinya baik, benar, indah, bijaksana, berharga dan berkualitas, dan wajib meningkatkan derajat kesadaran nilainya dalam hidup bersama dengan orang lain agar pergaulan hidup dan kehidupannya baik, bijak dan berharga.

\section{Pengertian Sopan Santun}

Pengertian sopan santun adalah suatu aturan atau tata cara yang berkembang secara turun temurun dalam suatu budaya dimasyarakat yang bisa bermanfaat dalam pergaulan antar sesama manusia sehingga terjalin suatu hubungan yang akrab, saling pengertian serta saling hormat menghormati. ${ }^{21}$

Sedangkan pengertian sopan santun dalam Islam adalah sopan santun terdiri dari 2 kata yaitu sopan dan santun. Sopan adalah hormat dengan takzim menurut adat yang baik.Sedangkan santun adalah baik dan halus budi bahasa dan tingkah lakunya, suka menolong dan menaruh belas kasihan. Dengan demikian pengertian sopan santun adalah suatu bentuk tingkah laku yang baik dan halus serta diiringi sikap menghormati orang lain menurut adat yang baik ketika berkomunikasi dan bergaul yang bisa ditunjukan kepada siapapun, kapanpun, dan dimana pun.

Pengertian sopan santun adalah sikap atau tingkah laku yang baik, hormat dan beradab serta diiringi oleh rasa belas kasihan dan berbudi halus yangbtercermin dalam tingkah laku, tutur kata, cara berpakaian, dan lain sebagainya. ${ }^{22}$

Kata sopan dalam kamus Besar Bahasa Indonesia (KBBI) mempunyai banyak arti, antara lain baik budi pekerti, tingkah laku, dan tutur kata yang baik, berlaku baik kepada

\footnotetext{
${ }^{20}$ Kama Abdul Hakam, Internalisasi Pendidikan Karakter di Sekolah Dasar. Disampaikan dalam Seminar Nasional di Universitas Indonesia tahun 2015, Disajikan di Balai Besar Pelatihan Kesehatan Jakarta 2016, dan Seminar Nasional di Institut Hindu Dharma Negeri (IHDN) Denpasar tahun 2016, 21.

${ }^{21}$ Taryati dkk, Pembinaan Budaya dalam Lingkungan Keluarga Daerah Istimewa Yogyakarta. Peny. Salamun. Departemen Pendidikan dan Kebudayaan, Direktorat lendral Kebudayaan Direktorat Sejarah dan Nilai Tradisional Proyek Pengkajian dan Pembinaan Budaya, 1995, 27.

${ }^{22}$ Sudarman Danim, Menjadi Penelitian Kualitatif, (Bandung: Pustaka Setia, 2012), 14.
} 
orang yang lebih tua serta tertib menurut adat yang baik. Sedangkan kata santun berarti halus budi pekerti dan suka menolong.Jika kedua kata ini digabungan menjjadi sopan santun yaitu budi pekerti yang baik dan tatakrama menurut adat yang baik.Sopan santun sangat erat sekali hubungannya dengan Akhlak karena seseorang yang mempunyai sopan santun sudah pasti mempunyai akhlak yang baik.

Sopan santun adalah suatu sikap atau tingkah laku yang ramah terhadap orang lain, sopan santun juga dapat di pandang oleh suatu masyarakat mungkin sebaliknya masyarakat juga dapat di pandang oleh masyarakat lain. Memang tidak mudah untuk menerapkan sopan santun pada diri kita sendiri, tetapi jika orangtua kita berhasil mengajarkan sopan santun sejak kecil maka kita akan tumbuh menjadi seseorang yang bisa menghormati dan menghargai orang lain. Kita dapat menunjukkan sikap sopan santun dimana saja, misalnya kita sebagai mahasiswa harus sopan terhadap dosen. Sopan santun diperlukan ketika seseorang berkomunikasi dengan orang lain, terutama kepada:

a. Orang yang lebih tua: orang tua, guru, atasan

b. Orang yang lebih muda: anak, murid, atau bawahan

c. Teman sebaya: setingkat status sosial

Bahwa seseorang bukan saja tidak menganggap dirinya lebih tinggi dari pada orang lain, melainkan menganggap orang lain lebih baik daripada dirinya sendiri. Sopan-Santun tidak selalu menghasilkan kebaikan hati, keadilan, kepuasan, atau rasa syukur, tetapi ini dapat memberikan seseorang paling tidak terlihat sopan, dan membuatnya tampak dari luar apa yang seharusnya menjadi benar-benar terhormat. Contoh sopan santun di Sekolah.Berikut beberapa poin sopan santun di sekolah:

a. Saling Menghormati. Orang tua harus mengajarkan kepada anak untuk saling menghormati kepada siapapun. Disaat anak sedang belajar di sekolah, anak harus menjaga sikap dan bicara secara sopan santun dengan guru, teman, orang tua, bahkan orang lain.

b. Cobalah selalu memanggil nama. Usahakan anak selalu memanggil nama kepada siapapun dan dimanapun. Misalnya di sekolah, memanggil orang tua, guru, teman, adik kelas, dan orang lain. Memanggil nama dengan sopan santun misalnya memanggil orang yang lebih tua dengan sebutan Bapak atau Ibu ditambah dengan nama, memanggil kakak kelas di sekolah dengan sebutan Kakak. 
c. Minta maaf dengan tulus. Ajarkan kepada anak untuk langsung meminta ma'af jika dia melakukan kesalahan meskipun cuma hal biasa.

d. Terima kasih dan tolong. Disaat Anda membutuhkan pertolongan kepada orang lain, seringlah mengucapkan kata tolong. Setelah itu ucapkan terima kasih setelah dia memberikan pertolongan.

e. Membantu orang lain. Ajarkan anak untuk saling membantu atau bahkan lebih bagus lagi sampai dia bisa menawarkan bantuan kepada orang lain yang membutuhkan.

f. Bersosialisasi dengan orang lain. Manusia adalah makhluk sosial yang harus bersosialisasi dengan orang lain. Dengan cara bersosialisasi kita akan mendapatkan rezeki, peluang usaha, teman, dan lain-lain.

Berikut beberapa hal yang bisa ketahui dalam bersosialisasi:

a. Berlatih kemampuan komunikasi

b. Memperluas wawasan

c. Melihat situasi ketika harus diam dan berbicara

d. Hati-hati dalam berkomentar

Pendidikan akhlak merupakan latihan membangkitkan nafsu-nafsu rububiyah (ketuhanan) dan meredam/menghilangkan nafsu-nafsu syaitoniyah. Pada materi ini peserta didik dikenalkan/dilatih mengenai:

1. Perilaku akhlak yang mulia (akhlaqul karimah/mahmudah) seperti jujur, rendah hati, sabar, sopan santun, dan sebagainya.

2. Perilaku atau akhlak yang tercela (akhlakul madzmudah) seperti dusta, takabur, khianat, dan sebagainya.

Setelah materi-materi tersebut disapaikan kepada peserta didik diharapkan memiliki perilaku-perilaku akhlak yang mulia dan menjauhi/meninggalkan perilaku akhlak yang tercela. $^{23}$

Bersikap lemah lembut dan sopan santun sudah dijelaskan dalam Al-Qur'an bahwa satu sifat utama bagi seorang muslim dan mukmin adalah besrsikap tegas terhadap orang kafir dan kasih sayang terhadap orang muslim. Dengan demikian dilarang sesama muslim untuk saling mengejek, mencemarkan nama baik dan memfitnahnya. Jangankan kepada sesama muslim, kepada yang beragama luar Islam pun dilarang berbuat seperti itu. ${ }^{24}$

\footnotetext{
${ }^{23}$ Heri Jauhari Muchtar, Fikih Pendidikan, (Bandung: Remaja Rosda Karya, 2005), 16.

${ }^{24}$ Heri Jauhari Muchtar, Fikih Pendidikan ..... 38.
} 
Dari uraian diatas dapat disimpulkan perilaku sopan santun adalah aktivitas seseorang yang dapat diamati oleh orang lain atau instrumen penelitian terhadap suatu perangsang atau situasi yang dihadapi berkaitan dengan hubungan kemasyarakatan, meliputi menghormati guru/orang yang lebih tua dari kita, tolong menolong, husnudzon dan menghargai orang lain, perilaku sopan santun merupakan cerminan dari akhlak mahmudah (akhlak yang baik).

Seorang anak haruslah memiliki akhlak yang baik sejak usia kecilnya, agar ia dicintai pada waktu besarnya, diridhoi Tuhannya, dicintai keluarganya dan semua orang. Seorang anak juga harus memiliki sopan santun dimanapun dia berada baik dilingkungan rumah dan dilingkungan sekolah.

\section{Sopan santun didalam rumah}

Setiap anak wajib memperhatikan sopan santun didalam rumahnya dengan menghormati kedua orang tuanya, saudara laki-lakinya, saudara perempuan serta setiap orang didalam rumah. Seorang anak tidak boleh melakukan sesuatu yang membuat marah salah seorang diantara mereka dan tidak boleh melawan kepada saudaranya yang lebih tua dan tidak boleh bertengkar dengan saudaranya yang lebih kecil serta tidak boleh mengganggu pelayan rumah. Apabila bermain, maka ia pun bermain dengan teratur tanpa berteriak dan bertingkah yang tidak pantas baginya, terutama bila mana didalam rumah ada salah seorang yang tidur/sakit.

2. Sopan santun anak terhadap Ibunya

Ibu adalah seseorang yang dengan jerih payahnya membesarkan anaknya dengan penuh kecintaan maka kewajiban seorang anak adalah mengamalkan sopan santun ini:

a. Hendaklah engkau mematuhi perintah-perintahnya disertai kecintaan dan penghormatan. Engkau kerjakan segala sesuatu yang menggembirakan hatinya. Engkau selalu tersenyum dihadapannya dan menjabat tangannya setiap hari serta mendoakannya panjang umur dalam keadaan sehat walafiat.

b. Hendaklah engkau waspada terhadap segala sesuatu yang menyakitkan hatinya. Janganlah berwajah cemberut bila ia menyuruhhmu melakukan sesuatu atau marah padamu. Jangan berdusta kepadanya atau memakinya atau berbicara dengan perkataan yang buruk dihadapannya, atau melihat kepadanya dengan pandangan yang tajam dan janganlah mengeraskan suaramu melebihi suaranya.

3. Sopan Santun Anak Terhadap Ayahnya 
Sopan santun anak terhadap ayahnya sama seperti halnya seorang anak sikap sopan santun kepada ibunya, mematuhi perintah-perintahnya dan mendengarkan nasihat-nasihatnya, karena seorang ayah tidak akan menyuruh kecuali dengan sesuatu yang berguna untuk seorang anaknya, dan tidak akan melarang kecuali dari sesuatu yang merugikan anaknya. Hendaklah senantiasa meminta keridhaan dengan menjaga kitab-kitab dan pakain-pakain serta semua peralatan belajar.

4. Sopan santun murid terhadap gurunya

Hormatilah seorang gurumu sebagaimana engkau menghormati kedua orang tuamu, dengan dududk sopan didepannya dan berbicara kepadanya dengan penuh hormat. Apabila ia berbicara, maka janganlah memutuskan pembicaraannya, tetapi tunggulah sehingga seorang guru selesai berbicaranya, dengarkanlah pelajaran-pelajaran yang diberikan oleh guru. Jika engkau tidak memahami sesuatu dari pelajaran-pelajaran yang telah disamapaikan, maka bertanyalah kepadanya dengan lemah lembut dan hormat, dengan mengangkat jari terlebih dahulu sehinggaseorang guru mengizinkan untuk bertanya, apabila iabertanya kepadamu tentang sesuatu maka berdirilah dan jawablah pertanyaan dengan jawaban yang baik.

Menghormati guru sangatlah penting kareana guru yang mengajarkan kita banyak ilmu dan ilmu yang diajarkan oleg guru tidak hanya untuk bekal didunia melainkan juga diakhirat. Berdasarkan wasiat-wasiat Nabi SAW ada beberapa point hak kepada guru sebagai berikut:

a) Hendaknya siswa bersikap tawaduk kepada gurunya, tidak menyelisihi pendapat dan arahannya. Ia selalu patuh sebagaimana orang yang sakit terhadap saran dokter. Ia hendaknya bermusyawarah apa yang diinginkan dan mencari ridhanya. Para pendidik hendaknya mengajarkan kepada anak bahwa patuh dan tunduk kepada guru merupakan kebanggaan dan kemuliaan yang agung.

b) Hendaknya seorang murid melihat gurunya dengan hormat dan meyakini bahwa gurunya mempuyai kedudukan yang sempurna, karean hali itu memudahkan baginya dalam mengambil manfaat dari gurunya.

c) Seorang murid harus mengetahui kewajibannya terhadap guru dan tidak melupakan jasanya, Syu'bah berkata; apabila saya menimba hadits dari seseorang maka saya akan menjadi budaknya seumur hidupku, ia juga berkata "tidaklah aku mendengar sesuatu (ilmu) dari seseorang, kecuali aku akan melayaninya dengan lebih banyak ilmu yang saya dengar darinya". 
d) Bersikap sabar kepada gurunya yang bersikap kasar dan keras. Murid seharusnya tidak menjadikan perangai keras tersebut sebagai penghalang dalam mengambil manfaat darinya. Apabila guru bersikap marah dan keras kepadanya, hendaknya ia memaafkan dan menganggap sebab kemarahan tersebut datang dari dirinya sendiri karean, hal ini akan melanggengkan cintanya kepada guru, menjaga hatinya, dan lebih bermafaat bainya didunia maupun diakhirat.

e) Seorang murid tidak boleh masuk ke ruang khusus bagi gurunya kecuali dengan izinnya, baik gurunya sedang sendirian maupun bersama orang lain. Apabila ia sudah meminta izin, tap tidak diizinkan hendaknya ia pergi dan tidak mengulangi permintaan izinnya. Jika merasa ragu, apakah gurunya tahu atau tidak, maka hendaknya tidak mengulangi perizinan lebih dari tiga kali, ketika hendak mengetuk pintu, hendaknya ia mengetuk pintu dengan halus atau memencet bel dengan pelan saja. Apabial guru jau dari pintu, maka tidak mengapa ia mengetuk pintu dengan sedikit keras sampai terdengar.

f) Hendaknya seorang murid duduk sopan didepan guru dengan bersikap tenang, tawaduk dan penuh penghormatan. Ia hendaknya melihat dan memperhatikan seluruh kalimatnya tanpa menoleh kekanan dan ke kiri yang tidak diperlukan.

g) Apabila seorang murid mendengarkan gurunya menyebutkan dalil sebuah hukum, suatu hal yang bermanfaat, menceritakan sebuah kisah atau mendedangkan sebuah syair hafalannya, dengarkanlah dengan penuh perhatian.

h) Itulah beberapa adab yang harus diajarkan kepada peserta didik. Adab-adab tersebut merupakan pembelajaran yang mulia dan hak bermasyarakat yang baik, ketika anak sudah terdidik dengan adab dan hak-hak tersebut sejak dini, mereka akan melaksanakan kewajiban yang harus dituanaikan kepada orang-orang yang harus ditunaikan kepada orang yang telah memberi ilmu dan membimbing mereka dalam membentuk kepribadian yang mulia, para guru atau pendidik. Tidak dapat dipungkiri bahwa pembentukan akhlak anak didik oleh para pendidik lebih diutamakan bila dibandingkan dengan ilmu dan budaya.

\section{Proses Internalisasi Nilai Sopan Santun di Sekolah}

Sikap sopan santun tidak sekedar hanya dipelajari di sekolah, namun sekolah perlu merancang mekanisme penerapan budaya sopan santun dalam kehidupan di sekolah. 
Disamping itu sekolah berkerjasama dengan keluarga untuk berperan membiasakan sikap sopan santun bagi anak mereka ketika di rumah dan di lingkungan sekitar.Peran orang tua di rumah dalam membiasakan sikap sopan santun bagi anaknya sangat penting mengingat sebagian besar waktu anak lebih banyak di rumah. Di sekolah mungkin lebih pada penguatan mengenai pentingnya dan makna dari berperilaku sopan santun. Dengan demikian kerja sama yang baik antara sekolah dan orang tua anak dalam mendidik anak tidak lagi hanya sebatas pada pembagian tugas atau orang tua menyerahkan sepenuhnya kepada sekolah namun perlu ada kerja sama dalam pelaksanaan proses pendidikan itu sendiri.

Pembudayaan merupakan suatu proses pembiasaan. Pembudayaan sopan santun dapat dimaksudkan sebagai upaya pembiasaan sikap sopan santun agar menjadi bagian dari pola hidup seseorang yang dapat dicerminkan melalui sikap dan perilaku keseharian. Sopan santun sebagai perilaku dapat dicapai oleh anak melalui berbagai cara. Pembudayaan sopan santun di rumah dapat dilakukan melalui peran orang tua dalam mendidik anaknya. Orang tua dapat melakukan hal-hal sebagai berikut:

1. Orang tua memberikan contoh-contoh penerapan perilaku sopan santun di depan anak. Contoh merupakan alat pendidikan yang sekaligus dapat memberikan pengetahuan pada anak tentang makna dan implementasi dari sikap sopan santun itu sendiri. Dyah Kusuma berpendapat :

“pembentukan perilaku sopan santun sangat dipengaruhi lingkungan. Anak pasti menyontoh perilaku orang tua sehari-hari.Tak salahlah kalau ada yang menyebutkan bahwa ayah/ibu merupakan model yang tepat bagi anak. Di sisi lain, anak dianggap sebagai sosok peniru yang ulung. Lantaran itu, orang tua sebaiknya selalu menunjukkan sikap sopan santun.Dengan begitu, anak pun secara otomatis akan mengadopsi tatakrama tersebut."

Contoh merupakan sarana yang paling ampuh dalam menanamkan sikap sopan santun pada anak, dengan contoh anak dapat secara langung melihat model dan sekaligus dapat meniru dan mengetahui implementasinya. Orang tua dapat menanamkan makna dari sikap sopan ini akan lebih mudah. Menanamkan sikap sopan santun melalui pembiasaan.Anak dibiasakan bersikap sopan dalam kehidupan sehari hari baik dalam bergaul dalam satu keluarga maupun dengan lingkungan. Seperti yang diungkapkan oleh Dyah Kusuma dalam yaitu:

"Kelak, anak yang dibiasakan dari kecil untuk bersikap sopan santun akan lebih mudah bersosialisasi.

Dia akan mudah memahami aturan-aturan yang ada di masyarakat dan mau mematuhi aturan umum tersebut. Anak pun relatif mudah menyesuaikan diri dengan lingkungan baru, supel, selalu menghargai 
orang lain, penuh percaya diri, dan memiliki kehidupan sosial yang baik.Pen-dek kata, dia tumbuh menjadi sosok yang beradab." 25

Pembiasaan merupakan metode yang paling tepat dalam pelaksanaan proses pendidikan karakter. Pelaksanaan pembiasaan ini tentu dialkuak melalui proses panjang yang harus dimonitor, dibimbing dan dinilai oleh guru maupun orang tua. Menanamkan sikap sopan santun sejak anak masih kecil, anak yang sejak kecil dibiasakan bersikap sopan akan berkembang menjadi anak yang berperilaku sopan santun dalam bergaul dengan siapa saja dan selalu dpat menempatkan dirinya dalam suasana apapun. Sehingga sikap ini dapat dijadikan bekal awal dalam membina karakter anak.

Pembudayaan sikap sopan santun di sekolah dapat dilakukan melalui program yang dibuat oleh sekolah untuk mendesain skenario pembiasaan sikap sopan santun. Sekolah dapat melakukan langkah-langkah sebagai berikut:

1. Peran sekolah dalam membiasakan sikap sopan santun dapat dilakukan dengan memberikan contoh sikap sopan dan santun yang ditunjukkan oleh guru. Siswa sebagai pembelajar dapat menggunakan guru sebagai model. Dengan contoh atau model dari guru ini siswa dengan mudah dapat meniru sehingga guru dapat dengan mudah menananmkan sikap sopan santun.

2. Guru dapat sekalu mengitegrasikan perilakuk sopan santun ini dlam setiap mata pelajaran, sehingga tanggungjawab perkembanagn anak didik tidak hanya menjadi beban guru agama, pendidikan moral pancasila, dan guru BP.

3. Guru agama, guru pendidikan moral pancasila dan guru BP dapat melakukan pembiasaan yang dikaitkan dalam penillain secara afektif. Penilaian pencapain kompetensi dalam 3 matapelajaran ini hendaknya difokuskan pada pencapain kompetensi afektif. Kompetensi kognitif hanya sebagai pendukung mengusaan secara afektif.

Dari sudut substansi, guru pembimbing mempunyai dasar keilmuan yang relevan sebagai jembatan menuju prilaku yang berbudi pekerti luhur. Mungkin yang perlu diperkaya dan dikembangkan adalah pemahaman tentang berbagai nilai dan norma serta aturan yang berlaku dalam masyarakat. Demikian pula halnya dengan metodologi, semua metode dan pendekatan yang bisa digunakan dalam bimbingan dan konseling berpeluang besar untuk membentuk dan memantapkan budi pekerti peserta didik.

\footnotetext{
${ }^{25}$ Dyah Kusuma, seperti yang dimuat dalam http://indteacher.wordpress.com/2009/05/06.
} 
Untuk menegaskan proses internalisasi sopan santun diperlukan sebuah upaya serius dalam menerapkannya. Seperti yang diuangkapkan oleh Sofyan Sauri dalam menelaah penerapan berbahasa santun, dia mengatakan bahwa dalamkonteks pendidikan, strategi belajar mengajar berbahasa santun dalam rangka membangun bangsa yang berkarakter santun dapat dikemukakan sebagai berikut:

a. Mengidentifikasi dan menetapkan spesifikasi dan kualifikasi perubahan tingkah laku yang diharapkan;

b. Memilih pendekatan belajar mengajar yang sesuai dengan kondisi siswa;

c. Memilih dan menetapkan langkah-langkah prosedur, metode, dan teknik yang tepat;

d. Menetapkan tolok ukur keberhasilan belajar mengajar.

Empat strategi dasar tersebut pada strategi belajar mengajar bahasa santun dapat dikemukakan sebagai berikut:

1. Menetapkan tujuan pembelajaran bahasa santun berupa perubahan tingkah laku yang diharapkan, yaitu kemampuan dan sikap santun dalam berbahasa yang mencakup kemampuan menggunakan bahasa dan tingkah laku santun. Tujuan pembelajaran bahasa santun terdiri atas:

a. siswa mampu mengatakan kosa kata yang santun dan mempraktekkannya dalam kehidupan sehari-hari;

b. siswa mampu membahasakan kata-kata santun dan mempraktekkannya dalam kehidupan sehari-hari.

2. Menetapkan pedoman umum pembelajaran bahasa santun dalam proses belajar mengajar berbagai bidang studi. Pedoman umum pembelajaran bahasa santun di dalam kelas mata pelajaran non- bahasa Indonesia dan agama adalah sebagai berikut:

a. Guru semua bidang studi menggunakan bahasa pengantar dalam pelajarannya dengan menggunakan bahasa yang santun;

b. Sedapat mungkin guru mengaitkan mata pelajarannya dengan nilai-nilai termasuk etika kesantunan;

c. Guru menegur siswa yang menggunakan bahasa tidak santun dalam proses belajar mengajar;

d. Guru mendorong siswa untuk menggunakan bahasa dan sikap santun.

Pada mata pelajaran Bahasa Indonesia:

a. Guru menggunakan bahasa pengantar dengan menggunakan bahasa yang santun; 
b. Sedapat mungkin guru mengaitkan mata pelajarannya dengan nilai-nilai termasuk etika kesantunan;

c. Guru menegur siswa yang menggunakan bahasa tidak santun dalam proses belajar mengajar;

d. Guru mendorong siswa untuk menggunakan bahasa dan sikap santun;

e. Guru menyiapkan pokok bahasan khusus bahasa santun yang terdiri dari konsep, jenis, dan sikap termasuk keterampilan berbahasa santun;

f. Guru bahasa Indonesia bertindak sebagai nara sumber dan pengawas siswa dalam berbahasa santun di sekolah.

Pada mata pelajaran agama:

a. Guru menggunakan bahasa pengantar dalam pelajarannya dengan menggunakan bahasa yang santun;

b. Guru mengaitkan mata pelajarannya dengan nilai-nilai akhlak termasuk etika kesantunan;

c. Guru menegur siswa yang menggunakan bahasa tidak santun dalam proses belajar mengajar;

d. Guru mendorong siswa untuk menggunakan bahasa dan sikap santun dalam kehidupan sehari-hari;

e. Guru agama menyiapkan pokok bahasan mengenai akhlak berbicara, konsep, jenis dan keterampilan berbicara yang berakhlak;

f. Guru agama bertindak sebagai nara sumber dan pengawas berbahasa santun di sekolah.

3. Menetapkan prosedur dan metode pembelajaran bahasa santun. Bagi guru non Bahasa Indonesia dan agama dapat ditempuh langkah-langkah sebagai berikut:

a. Membiasakan guru mengajar dengan menggunakan bahasa santun sebagai metode peniruan dan keteladanan;

b. Membiasakan siswa berbahasa santun;

c. Memberikan reward pada saat siswa berbahasa santun di kelas dalam bentuk pujian;

d. Memberikan kritik terhadap siswa yang menggunakan bahasa tidak santun di dalam kegiatan belajar mengajar.

Bagi guru Bahasa Indonesia ditempuh langkah-langkah sebagai berikut: 
a. Membiasakan guru mengajar dengan menggunakan bahasa santun sebagai metode peniruan dan keteladanan;

b. Membiasakan siswa berbahasa santun;

c. Memberikan reward pada saat siswa berbahasa santun di kelas dalam bentuk pujian;

d. Memberikan kritik terhadap siswa yang menggunakan bahasa tidak santun didalam kegiatan belajar mengajar;

e. Setiap memberikan contoh kata, kalimat, maupun wacana diselipkan aspek kesantunan;

f. Pokok bahasan sastra diupayakan kaitannya dengan bahasa santun;

g. Pokok bahasan pragmatik ditekankan pada keterampilan berbahasa

h. Evaluasi pelajaran bahasa Indonesia ditambah dengan pengamatan penggunaan bahasa santun siswa.

Bagi guru mata pelajaran agama dapat ditempuh langkah-langkah berikut:

a. Membiasakan guru mengajar dengan menggunakan bahasa santun sebagai metode peniruan dan keteladanan;

b. Membiasakan siswa berbahasa santun;

c. Memberikan reward pada saat siswa berbahasa santun di kelas dalam bentuk pujian;

d. Memberikan kritik terhadap siswa yang menggunakan bahasa tidak santun didalam kegiatan belajar mengajar;

e. Setiap memberikan contoh diselipkan aspek kesantunan;

f. Setiap pokok bahasan dikaitkan dengan kewajiban untuk pengamalannya dalam kehidupan sehari-hari;

g. Pokok bahasan akhlak ditekankan kepada pengetahuan dan keterampilan akhlak berbicara dan bertingkah laku;

h. Evaluasi mata pelajaran agama ditambah dengan pengamatan terhadap akhlak siswa.

Untuk kegiatan ekstra kurikuler dilakukan langkah-langkah sebagai berikut:

a. Membiasakan guru mengajar dengan menggunakan bahasa santun sebagai metode peniruan dan keteladanan;

b. Membiasakan siswa berbahasa santun;

c. Memberikan reward pada saat siswa berbahasa santun di kelas dalam bentuk pujian;

d. Memberikan kritik terhadap siswa yang menggunakan bahasa tidak santun di dalam kegiatan ekstra kurikuler; 
e. Setiap komunikasi guru dengan siswa digunakan bahasa santun;

f. Setiap kegiatan ekstra kurikuler yang dilakukan di dalamnya diselipkan aspek kesantunan;

g. Setiap kegiatan ekstra kurikuler diarahkan kepada pembinaan sikap.

\section{Kesimpulan}

1. Proses pembelajaran klasikal keagamaan disampaikan secara rutin dan terjadwal, pembelajaran yang disampaikan menggunakan Kurikulum 2013. Pembelajaran keagamaan secara formal dibelajarkan pada matapelajaran Pendidikan Agama Islam dan Budi Pekerti. Selain itu proses internalisasi nilai-nilai sopan santun bisa diserap dari beberapa mata pelajaran lain yaitu PKn, IPS dan lainnya.

2. Perilaku sopan santun siswa terhadap civitas akademiknya berlangsung dengan baik. Terbukti para siswa dengan mematuhi peraturan dalam berperilaku, berucap dan bertegur sapa dengan sopan, menegur teman sebaya secara santun, berbusana sesuai dengan kepantasan dan kode etik sekolah.

3. Untuk mewujudkan lingkungan bisa merawat sikap sopan santun maka kegiatan tambahan berupa kegiatan ekstrakurikuler keagamaan yang dilakukan secara rutin dan terjadwal, menjadikan para siswa lebih mengetahui tentang ilmu keagamaan, sehingga ajaran-ajaran keagamaan bias dipraktekkan secara langsung baik dilingkungan sekolah ataupun di rumah. Misalnya para siswa dipesankan untuk senantiasa menghormati para guru, menghargai teman sekolah dan menyayangi kedua orang tua dirumah. Berikutnya para siswa dibiasakan untuk bersikap sopan santun kepada para guru, sesame teman dilingkungan sekolah dan bersikap sopan santun kepada kedua orang tua sewaktu dirumah.

\section{DAFTAR PUSATAKA}

Bertens, Kees, Sejarah Filsafat Yunani, (Jakarta : Rajawali, 2001). Djahiri, A. K. , Pendidikan Nilai Moral; Hand Out Perkuliahan S-2 Program Studi Pendidikan Umum. (Bandung: PPS UPI, 2002).

Budimansyah, Dasim, Penguatan Pendidikan Kewarganegaraan Untuk Membangun Karakter Bangsa, ( Bandung: Widya Aksara Press, 2010). 
Danim, Sudarman, Menjadi Penelitian Kualitatif, (Bandung: Pustaka Setia, 2012).

Departemen Pendidikan Nasiona, Undang-undang RI No.20 tahun 2003 Tentang Sistem Pendidikan Nasional, (Jakarta : Depdiknas, 2003).

Fukuyama, F., Trust; Kebajikan Soail dan Penciptaan Kemakmuran, (Penerbit: Qalam, Yogyakarta, 1995), terj. Ruslani.

Goleman, Daniel, Emotional Intelegence; Kecerdasan Emosional, (Jakarta: Gramedia, 1990).

Hakam, Kama Abdul, Internalisasi Pendidikan Karakter di Sekolah Dasar. Disampaikan dalam Seminar Nasional di Universitas Indonesia tahun 2015, Disajikan di Balai Besar Pelatihan Kesehatan Jakarta 2016, dan Seminar Nasional di Institut Hindu Dharma Negeri (IHDN) Denpasar tahun 2016.

Kupperman, Joel. J., Character, (New York: Oxford University Press, 1991).

Lennox, C. , Do Companies Successfully Engage in Opinion shopping?: Evidence from The UK. (Journal of Accounting and Economics, 29, 2000).

Lickona, Thomas, Educating for Character, Mendidik untuk Membentuk Karakter; Bagaimana Sekolah Dapat Mengajarkan Rasa Hormat dan Tanggung Jawab, terj. Juma Wadu Wamaungu Editor; Uyu Wahyudin dan Suryani, ( Jakarta: Bumi Aksara, 2012).

Megawangi, Ratna, PendidikanKarakter, Solusi yang Tepat untuk Membangun Bangsa, (Cimanggis: Indonesia Heritage Foundation, 2004).

Muchtar, Heri Jauhari, Fikih Pendidikan, (Bandung: Remaja Rosda Karya, 2005).

Rokeach, M, The Nature of Human Value, (New York: The Free Press, 1973).

Sairin, Weinata, Pendidikan yang Mendidik, (Jakarta: Yudhistira, 2001)

Sumantri, E, Buku Materi Pembinaan Gnerasi Muda, (Jakarta : Universitas Terbuka, 1993).

Tamsikudin, Pengembangan Model Pembinaan Akhlak Dalam Pembentukan Pribadi Sehat Di Lembaga Pemulihan Sosial (Studi Kasus di Balai Pemulihan Sosial Wanita Tuna Susila Cirebon), (Bandung: UPI Bandung, Disertasi, 2012).

Taryati dkk, Pembinaan Budaya dalam Lingkungan Keluarga Daerah Istimewa Yogyakarta. Peny. Salamun. Departemen Pendidikan dan Kebudayaan, Direktorat lendral Kebudayaan Direktorat Sejarah dan Nilai Tradisional Proyek Pengkajian dan Pembinaan Budaya, 1995.

Tim BSNP, Paradigma Pendidikan Nasional Abad XXI, (Jakarta: Buletin BSNP, 2012). 